\title{
DIE SOGENAAMDE KATEGISMUSPREEK - VANWAAR, WAAROM EN HOE?
}

\author{
Bouke Spoelstra \\ Departement Diakoniologie \\ Potchefstroomse Universiteit vir $\mathrm{CHO}$ \\ POTCHEFSTROOM
}

\begin{abstract}
The Heidelberg Catechism originated in 1563 in the Paltz by political authority of the head of state for the purpose of education in schools and for general religious instruction. This document received the status of an official doctrinal creed (confession of faith) in the churches in the Netherlands at the Synod of 's-Gravenhage in 1586. Unity of faith as confessed determined the being of the church and ecclesiastical unity. The same synod therefore prescribed weekly preaching of the main content of the Christian doctrine and referted to the chapters of the Heidelberg Catechism as agenda for this purpose. The Church Order (an. 68) still maintains this prescription for the GKSA today. A lack of understanding of the real meaning and purpose of doctrinal preaching gave rise to a wrong perception that the Calechism as such is ordered by ecclesiastical authority to be preached In this article it is asserted that in the so called 'catechism-sermon' more than one pericope from Scripture should be used in context - rather than to focus on text in isolation - to highlight a certain section in the Heidelberg Catechism. In homiletics this kind of semmon should also be treated according to its own genre in homiletics.
\end{abstract}

\section{INLEIDING}

Ons hoor vandag vrae opgaan oor die sin en betekenis van die 'gewoonte' om 'kategismusprediking' te onderhou (vgl. GKSA, 1990; Schulze, 1988:24; Schulze, 1989). Daar is tekens dat 'kategismusprediking' in die GKSA in verval is, ten spyte daarvan dat artikel 68 van die Kerkorde nie openlik betwyfel word nie. Sommige skryf met groot stelligheid 'n metode van 'teksprediking' by alle kategismusprediking voor (Grobler, 1983:80).

Hierdie studie wil na die kategismuspreke kyk in die lig van die oorspronklike bedoeling dat "de somma der Christlijcke Leere ... die teghenwoordigh in de Nederlandtsche Kercken aengehenomen is" gereeld gepreek moet word (Pont, 1981:161, 184). Met die oog daarop moet gekyk word na waar kategismusprediking vandaan kom, waarom dit noodsaaklik is en hoe dit behoort te geskied. 


\section{DIE HERKOMS VAN KATEGISMUSPREDIKING}

Verskillende kategismusse het in verskillende lande gedurende die Reformasie die lig gesien om die reformatoriese geloof te omlyn, te voed, te versterk en te propageer (Honig, 1925:430). Die Heidelbergse Kategismus is in 1563 soos enige ander kategismus (van byvoorbeeld Luther, Calvyn of die Engelse Common Prayer Book) in die Paltz ontwerp. Die oorspronklike opdrag het van die staatshoof uitgegaan om 'n leermiddel vir ondenwys en kategese daar te stel (Oberholzer, 1989; Steenkamp, 1989). Keurvors Frederik III wou die verwarring tussen Rome, die Lutherane en Calvyn uitskakel en kragtens die Germaanse ius patronatus in sacra sy onderdane innerlik konsolideer deur middel van 'n 'eenvormige leer en kerkregering'. Met die oog op die eenheid in geloof en aanbidding, en hoegenaamd nie met die doel om 'n geloofsbelydenis daar te stel nie, het die Heidelbergse Kategismus die lig gesien (Steenkamp, 1989:618,624; Wielenga, s.j.:9; Grobler, 1983:11). Dié kategismus was nie die produk van besinning oor geloof in 'n kerklike konsilie nie maar was bedoel om kerk-asgelowig-wees prakties te dien. Die kategetiese gebruik daarvan wou doelbewus mense laat bely wat hulle glo (vgl. Spoelstra, 1990:55).

Hierdie kategismus het groen gebly (Wielenga, s.j.:15) en in aansien toegeneem "als middel om de Schrift zelf te laten spreken ... Wij kunnen niet op de manier van zekere biblicisten, aan de kerkelijk denkwerk voorbij gaan zonder schade aan onze geloofskennis te lijden" (Ibid:21). Die gebruik om die kategismus te preek is egter 'n ander saak. Sommige dink vandag dat die Kerkorde van die Sinode van Dordrecht 1619 die Kategismus as preekstof voorgeskryf het en dat die GKSA dit net formeel so oorgeneem het.

'n Kategismus as geformuleerde geloof was vir Calvyn belangrik hoewel kategismusprediking nie in Genève voorgeskryf was nie. "The entire sphere of theology and church proclamation boils down to this: interpretation. For Calvin that means not simply patching biblical texts together, "but expressing in plainer words those things which are perplexing and difficult for us in the Scriptures' (Milner, 1970:103). Die Heilige Gees "has bestowed the gift of interpretation upon the church - to be exercised by ministers - so the congregation has been given the right of 'examination or discrimination". Calvyn erken "a twofold examination of doctrine, private and public" wat die gelowige tweesydig deur "the Word and Spirit of God" doen (Milner, 1970:104). Die interpretasie van die Skrif is vir 'n ware geloof van beslissende betekenis (HK Son. 7).

Die oorspronklike doel van die kategismus was "mondeling onderwijs in de christelijke religie" met die doel om 'n katkisant ("catecumeen") te katkiseer. Luther was die eerste een (1525) om sy boekie om die jeug te onderwys 'n "Catechismus" genoem 
(Honig, 1925:430). Gedurende die hitte van die Kerkhervorming het teen 1527 in Lutherse kerke die gebruik ontstaan om ook kategismuspreke uit Luther se kategismus te hou (Van 't Veer, 1942:168). Calvyn sou dit kon goedkeur omdat hy van oordeel was dat die Twaalf Artikels in die vroeg-Christelike kerke as kategismus in kategese gebruik en gepreek is (Ibid: 167 e.v.).

Die Twaalf Artikels het in die vroeg-Christelike kerke effektief die lyn getrek tussen die missa catechemenorum (erediens waarby kinders en proseliete betrokke is) en die missa fidelium (die erediens met Nagmaalviering uitsluitlik vir belydende gelowiges). lemand moes met die Credo sy geloof kon bely om tot die missa fidelium toe te tree (Van 't Veer, 1942:174, 250; Van der Leeuw, 1946:135).

Gedurende die Reformasie in die Nederlande, nog voor die kerke in sinodes saamgekom het, het predikante gebruike van die Paltz nagevolg en uit die Heidelbergse Kategismus gepreek om die gereformeerdes met die Skrif in die geloof op te bou en teen Roomse en Anabaptistiese dwalings weerbaar te maak (Hoekstra, s.j::369; Grobler, 1983:13). Die gereformeerde liturgie op Sondae het begin met 'n gebed dat God die gemeente in 'ware geloof' sal bou en bewaar. Onmiddellik daarna is met die Twaalf Artikels belydenis van die geloof gedoen (Biesterveld \& Kuyper, 1905:74 art. 44).

Indien ons let op die groot rol wat die Twaalf Artikels (Credo) kategeties en liturgies in die vroeë kerke gespeel het, val dit op dat die Credo ook 'n groot deel van die Heidelbergse Kategismus beslaan (Sondae 7 tot 23). Die Credo moet die ware saligmakende geloof omlyn (HK V/A 22,59). Die uitleg van die Twaalf Artikels word net met die leer oor die Wet (Sondae 2-5, 33-44) en gebed (Sondae 45-52) aangevul. Die Heidelbergse Kategismus voeg slegs die geloof oor die sakramente teenoor die dwaalleer van Rome en die Anabaptiste by (Sondae 25-31). As ons daarop let dat die Twaalf Artikels, die Wet en die Onse Vader die kategetiese leerstof in die vroeë kerke uitgemaak het, is dit duidelik dat die Heidelbergse Kategismus inhoudelik direk by die geloofsopvoeding en geloofsbelydenis van die vroeë kerke aansluit.

Aanvanklik was die preke homilieê oor die kategismus (Biesterveld \& Kuyper, 1905:87). Die gesamentlike kerke handel in die Provinsiale Sinode van Dordrecht 1574 vir die eerste keer oor die 'gewoonte' van kategismuspreke (Biesterveld, Kuyper, 1905:74,87; Pont, 1981:161). In 1581 bepaal die kerke dat die kategismuspreke die Skrif deeglik moet verklaar met exegemata (Biesterveld \& Kuyper, 1905:176). Die preke moes dus die Skrif laat spreek oor wat in die Kategismus geformuleer is. Wanneer die Libertyne (Coolhaes e.a.) die suiwerheid van die gereformeerde leer en as gevolg daarvan die eenheid in geloof, dit wil sê die kerk, in die gedrang bring, bepaal die kerke in 1586 in die kerkorde dat die hoofsom van die Christelike leer aan 
die hand van die Heidelbergse Kategismus oor die tydperk van ' $n$ jaar deurgepreek moet word (Hoekstra, s.a:370; Pont, 1981:161). Die Kerkorde van Dordrecht het in artikel 68 bepaal: "De dienaars zullen alomme des Zondags, ordinaarlijk in de namiddagsche predikatie, de somma der Christelijke leer in den Catechismus, die tegenwoordig in de Nederlandsche kerken aangenome is, vervat, kortelijk uitleggen ..." (Pont, 1981:184. Vgl. Spoelstra, 1989:368).

Hieruit is twee sake duidelik: die bedoeling was nie om die kategismus as sodanig nie, maar om die hoofinhoud van die Christelike leer te laat preek en dat die kategismus as agenda (hulpmiddel) met die oog daarop gebruik moes word. So het naas ander preke die sogenaamde kategismuspreek ontstaan (Hoekstra, s.j.:123). Die benaming kategismuspreek is dus in 'n sekere sin misleidend. Gevolglik praat ons van die 'sogenaamde kategismuspreek' in hierdie artikel omdat die kerkordelike voorskrif gerig was op die Christelike geloof en nie op die Kategismus as sodanig nie. Die motief was om die geloof wat God geopenbaar het, vas te hou (te glo en te bely) soos Hy dit bekend gemaak het, sodat die gemeente daadwerklik daarby kon lewe en sterwe (HK Son. 1,7,23).

Die Heidelbergse Kategismus het besondere verdienstes waarom dit as agenda vir die stelselmatige verkondiging van die Christelike geloof gekies is. Hierdie kategismus is 'n 'versoenende dokument' wat verskillende gesindhede in die Paltz kon verenig. Dic meer polemiese vraag en antwoord 80 sou die Keurvors bygevoeg het (Velthuysen, 1989:648). Die Heidelbergse Kategismus het in sowel die Paltz as in die Nederlande die "totale volkslewe hervorm" (Oberholzer, 1989:603 e.v.). "Until we have a better outline of God's truth for God's church, we should teach and preach the Heidelberg Catechism ... It is an existential, personal and corporate confession of what it means to be Christian and to be the church of Christ" (Kuyvenhoven, 1989:6; vgl. Dijkstra, 1980:40 e.v.; Timmer, 1989).

\section{VAN LEERBOEK TOT GELOOFSBELYDENIS}

Kategese en prediking is albei gestaltes van Woordverkondiging, en albei hou elemente van onderrig (didache) in (Mat. 28:19 "leer hulle"), maar' $n$ kategismus en 'n preek is nie dieselfde nie. ' $n$ Kategismus word in die kategese gebruik om bepaalde fasette van die openbaring in die Skrif mee te deel wat tot oortuiging en openbare belydenis van geloof moet voer. Daarom moes onderwysers in Nederland en Suid-Afrika Sondagmiddae die kinders na die sogenaamde 'openbare katkisasie' (kategismuspreek) vergesel het. $\mathrm{Na}$ die diens moes die predikant, onderwyser en ouers die preek behandel om te kyk of die kinders die gereformeerde leer as Bybelgetrou verstaan (De Wet \& Coetzee, 1943:66-73; vgl. Van 't Veer, 1942:17 e.v., 388 e.v. i.v.m. Genève). Die 
kategese vorm die leefruimte "waarin die dooplidmate in die gemeente gesosialiseer word. In die kategese word die siening van die belydenisskrifte kognitief oorgedra en in die praktyk van die erediens en preek word dit ervaar" (Pieterse, 1989:589). Kategese met die Heidelbergse Kategismus as leermiddel het gewoonlik afgeloop nadat openbare belydenis van geloof (konfirmasie by die Lutherse geloof) plaasgevind het.

Die Heidelbergse Kategismus het spoedig in die Nederlandse Kerke meer as ' $n$ middel geword om dooplidmate in die gemeente 'te sosialiseer'. Dit het reeds in 1571 by die eerste sinodale byeenkoms te Emden as leerboek kerklike status verkry, maar dit het nog nie as Formulier van eenheid gefunksioneer nie (vgl. Pont, 1981:103 artt. 2 en 5). In 1574 word die Kategismus as enigste leerboek en toets in verband met die aflê van geloofsbelydenis aanvaar (Biesterveld \& Kuyper, 1905:62 (2)). Die stryd teen Rome, die Anabaptiste en Libertyne maak dit nodig om die eenheid van geloof in die Kerkorde te verskans (Pont, 1981:132(8), 137(53)). In 1586 mag skoolmeesters die kategismus in die plek van die belydenis onderteken. Dieselfde Sinode bepaal dat die leer volgens die kategismus gereeld gepreek moet word (Biesterveld \& Kuyper, 1905:205(48) vgl. 209 (61)). Wanneer die Heidelbergse Kategismus in 1586 tot geloofsbelydenis verklaar word (Oberholzer, 1989:603 e.v.), omdat dit die een ware geloof of homologia wat die gemeente bely (Grobler, 1983:54 e.v.), formuleer, word dit ook as agenda vir preke oor die geloof voorgeskryf. Voor 1586 was die Heidelbergse Kategismus ' $n$ middel om die gemeente Skrifwaarhede te leer. Wanneer dit as geloofsbelydenis aanvaar word, spreek die kerke daarin uit wat hulie op grond van die Skrif glo. Tog bedoel die Kerkorde-artikel nie om die Kategismus self te 'preek' nie. Die artikel van 1586 praat van die "somma der Christelijker leere in den Katechismo" wat gepreek moet word (Biesterveld \& Kuyper, 1905:209(61)).

Die geloofsbelydenis van 'n kerk is sy vlag, die "akkoord van kerklike gemeenskap" (Lindeboom s.j.:189) wat individueel en gesamentlik bind (Nauta, 1969) en mense tot kerk verenig (HK Son. 21). Wanneer kerke die Heidelbergse Kategismus tot Formulier van Eenheid aanvaar, sê hulle daarmee dat die Heidelbergse Kategismus in alles met die Woord van God ooreenkom totdat die teendeel bewys is. Die Skrif bly die hoogste gesag, die norma normans ten opsigte van die kategismus (NGB, 7).

Daaruit kan ons die volgende vir die prediking aflei: die kategismus is nie aan die Skrif gelyk nie en kan nie 'n bron vir die prediking vorm nie. As geloofsbelydenis formuleer dit egter geloofswaarhede uit die Skrif en daardie waarhede kan weer die Skrif waaruit die waarhede geformuleer is in die prediking aan die orde stel. As ons ' $n$ geloofsbelydenis 'n konsensus van gemeenskaplike eksegese kan noem, staan die geloofsbelydenis ente hoër in aansien as ' $n$ bepaalde dominee se eksegese vir sy preek. Die hoofsom van die Christelike geloof in dié belydenisskrif bied dus preektemas 
waarin die Gees met diakroniese Skrifgebruik die gemeente in geloof opbou.

\section{DIE GELOOFSBELYDENIS BIND DIE KERK AS GESTAL.TE VAN DIE KONINKRYK VAN GOD SAAM}

Christus tipeer die sin en aard van sy koms na die wèreld met die koms van die koninkryk van God (Mark. 1:14,15; Luk. 4:43; Mat. 13:19; Hand. 1:3,6; 1 Kor. 15:24 ens.). Die woord koninkryk beteken oorwegend die koningskap, heerskappy of regering van God (Ridderbos, 1950:41; vgl. 36). "God kwam sprekend binnen in de geschiedenis van het mensenleven" (Trimp, 1989:553 e.v.). Die kerk "ontstaan onder de prediking, daar waar de Evangelie des Koninkrijks geloofd wordt" (Noordmans in Haarsma, 1967:65). Die kerk wat Christus as Here (Koning) gehoorsaam, maak die koninkryk sigbaar waar hulle glo wat God geopenbaar het (Mat. 16:16; Joh. 20:28 e.v.; Rom. 10:12, 14:8; 1 Kor. 8:6; Ef.1:22, 6:9; 1 Tim. 6:15 ens.). Die ekklesia (kerk) is die volk wat in "die eenheid van 'n ware geloof" ( HK Son. 21) vergader word en daarin kom die koninkryk van God na vore ( HK Son. 48; NGB 27,29,31). Elke plaaslike kerk maak die liggaam van Christus sigbaar in so ver hulle dieselfde Woord en Gees glo en gehoorsaam en in liefde verenig word (Calvyn, 1951:320 (10); Spoelstra, 1978:4 e.v., 20 e.v.; 1984:20 e.v.); daarom is geloof as daad en as inhoud 'n saak van gehoorsaamheid.

Ons ken God deur die werk van die Gees uit sy Woord wat ons glo (Joh. 1:18; 16:13; 17:3). In die Geloofsbelydenis soos in die Heidelbergse Kategismus verwoord die kerke wat hulle God hoor sè het en as sodanig gee die Kategismus, dikwels in een formule, weer wat die Skrif op talle plekke sê. Dit beteken dat die kerke, hierdie gelowiges, één en dieselfde antwoord op die Woord en Gees van God gee. Om die kerk te wees en te bly, moet die gelowiges hulle homologia (Heb. 4:14) koester en bewaar.

Ons vind vandag twee lynreg teenoormekaarstaande standpunte oor die wese van die kerk en wat die eenheid van die kerk is: 'n organiese opvatting (Calvyn, 1951:319-321; Spoelstra, 1978:4 e.v., 20 e.v.; 1984:20 e.v.; 1988:37 e.v.; 1989:4 e.v.) en daarteenoor 'n organisatoriese, institusionele of formele opvatting (Spoelstra, 1989:8, 13 e.v; 1986:4 e.v). Die basiese verskil veroorsaak twee verskillende opvattings oor die funksie van die geloofsbelydenis.

Volgens die organiese beeld van die Hoof en die Liggaam (1 Kor. 12:12-13:13; Ef, $1: 22,23$ ) het kerkwees te doen met "het belijden van Christus, de erkenning van de Godsopenbaring ... Door het geloof in de God van de Openbaring ... onstaat 'de heilige familie' ... waaraan Abraham en alle heiligen ... deelhebben ... De eenheid 
van de kerk is dus ... een eenheid in geloven ... een mistische eenheid. $\mathrm{Zij}$ is daarom ... Godswerk". Haarsma verwys verder na Noordmans wat sê: "De eenheid der kerk is dus ... allereerst en wezenlijk een eenheid en verbondenheid van de leden door het zelfde geloof" (Haarsma, 1967:138 e.v.). Die ware kerk is slegs daar waar "het ganse getal der uitverkorenen door de band des geloofs tot én gemeenschap samenkomt en tot één volk Gods ..." deur die geloof saamgebind is. Daarom is die "eenheid der kerk" nie in 'n sigbare organisasie of instituut vervat nie, maar "in het geloof gelegen" (Polman, s.j.:264 e.v.) en daarom hef geloofsverskille eenheid op al bly die uiterlike organisasie onder die naam kerk bestaan (vgl. NGB, 29; Calvyn, Institusie IV. 2(12)).

Rome en Calvyn aanvaar as basis vir eenheid en gemeenskap die organiese "gemeinschaft (communitas) des Glaubens" waardeur "Christus sich mit den Gläubigen vereinigt" (Gassman, 1968:305). Die kerk is eenheid omdat "die Kirche in ihrem Wesen primär bestimmt is durch die einzelnen Menschen, die ihr als Glieder angehörigen. Die Gliederschaft aber hat ihren Grund im Glauben. So ist denn der Glaube was die Kirche zur Kirche macht" (Gassmann, 1968:28; vgl. Küng, 1973:82 e.v.).

Luther onderskei skerp tussen die onsigbare volk van God in die ryk waar God regeer en die sigbare preekinstituut in die ryk (ryk van die natuur) waar owerhede regeer. Nogtans is die kerk vir hom ook "congregatie van gelovigen ... Deze gemeente of vergadering omvat allen, die in rechte geloof, hoop en liefde leven: Eén doop, eén geloof, éen Heer (Ef. 4:5) ... Zo is de Christenheid een geestelijke vergadering der zielen in éen geloof ... Alleen het rechte geloof maakt de Christen" (Polman, s.j. :241 e.v.). Let op hoe 'kerk' hier nie as 'n objektiewe instituut teenoor die gelowiges gestel word nie.

Samevattend:

In die vroeg-Christelike kerke, by Rome en die Reformatore word die kerk allereers organies as 'n liggaam van gerealiseerde gehoorsaamheid aan die Koning verstaan. Die gehoorsaamheid kom volgens die Reformasie na vore in een ware geloof waarin die Woord en Gees gehoorsaam word ( HK Son. 21). Volgens die Skrif (Snyman. 1977:45) en die gereformeerde belydenis (NGB 27-29; • HK Son. 21) is die kerk universeel en plaaslik, onsigbaar en sigbaar, altyd 'n eenheid wat deur geloof saamgebind word. Die geloof bepaal dat die gelowiges die Wet van God in bulle lewe voorop stel. Kortom, die wesenlike van die kerk, universeel en plaaslik, word bępaal deur die toets of die Here in leer en lewe gehoorsaam word (NGB 29). Die reëlmatige prediking van die hoofsom van die Christelike geloof aan die hand van die Kategismus as belydenisskrif wou derhalwe die eenheid dien van die kerk as mense wat God in leer en lewe gehoorsaam (d'Assonville, 1976:82 e.v.; Grobler, 1983:106). 
Lynreg teenoor hierdie opvattings van die koninkryk staan die rasionalistiese en formele begrip van die kerk wat deur die invloed van Schleiermacher baie diep in die Westerse wêreld ingeslaan het. Die kerk is al meer beskou as 'n objektiewe organisasie (vereniging) wat mense oprig om hulle godsdiens te beoefen. In die konstitusie kan belydenisskrifte dan die 'kerk' as organisasie bekend stel. Die 'kerk' handel met 'n geloofsbelydenis soos die lede in sinodes besluit (Du Plooy, 1989:6; Polman, s.j.:19,22).

Die Reformatoriese belydenisskrifte word dikwels as blote historiese rigtingwysers beskou (vgl. Polman, s.j.:15 e.v.). Die baie algemene idee is dat die 'kerk' as genootskap 'n regspersoon is (Spoelstra, 1989:14 e.v.) wat bepaalde belydenisskrifte besit soos iemand 'n boek besit. Die belydenisskrifte moet ter wille van die kerk as organisasie gepreek word. Die belydenisskrifte van die kerk word nie meer as die credo van die 'lidmate' beleef nie en kan volgens dié opvatting nie soos die Skrif "gemeen accoord" uitdruk nie (Polman, s.j.. 15 e.v.; Bouwman, 1925:276 e.v.). Hierdie opvatting van objektiewe belydenisskrifte dra direk by tot die verval van die sogenaamde kategismuspreke omdat hierdie preke kwansuis nie Skrifprediking kan wees nie maar 'kerkleer' in plaas van die Skrif weergee. Volgens hierdie opvatting word die geloofsbelydenis dus eerder in verband met die kerk as organisasie as in verband met Skrifgeloof gesien.

Ursinus stel die doel van die Kategismus baie duidelik in terme van die kerkvergaderende werk van God. Hy wil met die kategismus "door de stem Gods en de verkondiging van het woord" mensen "uit het rijk des Satans" oproep om Gods Woord te omhels en om in "de vergadering der geroepenes van God bijeengebracht tot kennis des evangelies" te bring (Ursinus, 1886:397). Prediking is nie slegs die meedeel van kennis nie, maar moet die impak van die waarheid met nadruk in die gedagtes van mense vestig om hierdie waarheid lewend te mak. Gevolglik moet prediking individueel en gemeenskaplik verkondig dat God heers en mense moet die koningskap aanvaar (Jung, 1986:35, vgl. Mark. 1:14; Luk. 4:43). Kategismus en prediking is intiem verwant.

Hierdie "zichtbare kerk" is 'n vergadering wat "de reine en onbedorven leer van wet en evangelie omhelzen en in belijden gehoorzaamheid jegens die leer betoonen" (Ursinus, 1886:398). Die vernaamste kenmerk van die kerk is die "belijdenis van de ware, onbedorven en juist opgevatte leer van wet en evangelie" (Ibid: 403). Die voorskrif in die Kerkorde van Den Haag (1586) om die Christelike leer aan die hand van die Kategismus te preek, het dus net ten doel om die gemeente, individueel en gesamentlik, in staat te stel om te kan bely wat God in sy Woord leer.

In hierdie prediking val alle nadruk op die eenheid in ware geloof wat God deur sy Gees en Woord werk. Elkeen moet in ware geloof eksistensiëel 'lewende lid' van die een universele kerk kan bly ( HK Son. 21; NGB, art. 27). Die gemeente op 'n bepaalde 
plek is slegs die universele kerk in so ver hulle deur 'n ware geloof aan Christus verbonde en in Hom ingelyf is (vgl. NGB 27,28; Doopformulier; Snyman, 1977:45). Wie die leer in ooreenstemming met die Bybel bely, maak die kerk uit, selfs al sou hulle nog organisatories onder die pousdom verkeer (Calvyn, 1951:331(12)).

Die prediking van die hoofsom van geloof dien ook praktiese en pastorale doeleindes. Die Christelike geloofsleer het te doen met die deurdink, verstaan, aanvaar, deurleef, beleef en uitleef van Skrifwaarhede wat "lidmate sodoende weerbaar maak teen dwalinge ... wat die kerk bedreig" (Grobler). Dit verhoed dat predikante net hulle geliefkoosde temas preek en verseker dat die hele raad van God gepreek word - ook die moeiliker aspekte, wat hoër eise aan die prediker stel. Kategismusprediking kan reeds op pragmatiese gronde verdedig word (Grobler, 1983:104 e.v.).

Die bepaling in die Kerkorde van 1586 om jaarliks die hooflyne van die Christelike geloof deur te preek, vloei regstreeks uit die belydenis dat dit 'nuttig en goed is' dat die regeerders van die Kerk onder mekaar "n bepaalde orde' instel wat 'die liggaam van die kerk' in stand hou. "Ons aanvaar derhalwe slegs wat kan dien om eendrag en eenheid te bewaar en te bevorder om alles in gehoorsaamheid aan God" te onderhou (NGB 32). Eenheid in die hoofsake van die Christelike geloof is conditio sine qua non vir ware kerkwees. Prediking wat gerig is op hierdie eenheid in geloof verskaf uitnemende pastorale sorg om die kerk as vergadering van gelowiges in Christus te bewaar (vgl. Spoelstra, 1984:20 e.v.; 1989:297 e.v.; 368 e.v.). Abraham Kuyper (De Heraut (13.3.1888) het opgemerk dat die predikant "allermeest en allervoornamelijk ste en principaalste" pastor van God se volk op die kansel is waar hy uit die Woord 'leer'. Prediking van die geloofsleer is al pastorale dogmatiek genoem omdat die sondaar wat die evangelie aanneem, die geloofwaarhede persoonlik moet glo. Die Kategismus is so opgestel dat iemand daarmee subjektief die waarhede wat God gee om te glo met die totaliteit van hart, siel en verstand vir homself kan toeëien (Noordmans in Haarsma, 1967:16. Vgl. Dijkstra, 1980:40 e.v). Die Kategismus is toegespits op die alledaagse lewe, lewensvrae, lewenskunde en lewenskuns aan die hand van die Woord en Wet van God (Engelbrecht, 1989:638 e.v). Wie die Heidelbergse Kategismus as objektiewe 'leerstuk van ons kerk' wil preek, verstaan nie die funksie van lewende geloof in kerkwees nie.

Die prediker moet self met volle oorgawe en in die gloed van Bybelse oortuiging die belydenis van die volk van God vanaf die kansel vir elke hoorder individualiseer en konkretiseer. Die persoonlike $m y$ en $e k$-taal van die Heidelbergse Kategismus leen hom uitstekend om die sola scriptura-beginsel van die Reformasie toe te pas en na te leef (Engelbrecht, 1989:634; Dijkstra, 1980:40 e.v.). 
Die sogenaamde kategismuspreek - vanwaar, waarom en hoe?

\section{WEERSTAND TEEN KATEGISMUSPREKE}

Die beroep op die gesag van die natuurlike rede van die individu wat uit die humanisme van die Rennaissance opgekom het, wou niks van gemeenskaplike belydenis weet nie (vgl. Hanekom, 1951:xiv). Tydens die Reformasie ontken die Libertyne en Remonstrante dat die belydenis enige gesag dra (Grobler, 1983:20, 26 e.v.). Hulle wou vryheid vir die rede van die outonome individu inruim en het gesê dat die Roomse pous moet nie met ' $n$ 'papierpous' vervang word nie. Hulle beveg primèr die formele feit van 'n belydenisskrif om hulle besware teen wat bely word te verbloem. "Die geskiedenis in Nederland toon dat die neiging om met die kategismusprediking weg te doen, altyd gebeur op 'n tydstip wanneer daar minder erns met die handhawing van die suiwere leer gemaak word" (Grobler, 1983:32). So is 'kategismusprediking' in Nederland ook tydens die hoogty van die Liberalisme (1860) afgeskaf (Haitjema, 1962:13). Ook in Suid-Afrika het die Liberalisme dié prediking van die belydenis met afkeer bejeën (Hanekom, 1950:181). Hierdie afkeer van die belydenis lei onvermydelik in die kerklike lewe na stryd tussen rigtings, "een verdeeldheid in denken, geloven en godsdienstige beleving, meer dan in structuur en organisatie van de Kerk" (Haarsma, 1967:137).

Die Dopers het tydens die Reformasie by die humanisme aangesluit en 'mensgemaakte' konfessies met 'n beroep op die vryheid van die Gees om die Bybel te verklaar, afgewys (Spoelstra, 1975:41,49). Hulle was teen die feit van 'n belydenis gekant, ongeag watter inhoud daarin bely word. Verskillende vorme van biblisisme verwerp die konfessies as mensewerk en wil self weer alle waarhede direk uit die Bybel aflei (De Klerk, 1937:17,23 e.v.). Die filosoof Kant se teenstelling tussen teorie (leer) en praktyk (lewe) het diep ingeslaan. Geloofsbelydenisse bevat daarvolgens kerklike teorie of teologie terwyl die geloof om praktiese godsdiens vra (Dijkstra, 1980:46; Schulze, 1988:27 e.v.).

Schleiermacher het op voetspoor van Kant skerp onderskei tussen belydenis as wese (objektief) en bely as vroomheid (subjektief) (Schleiermacher, 1968:24). Hy wys prediking wat die belydenis belig af omdat die objektiewe leer na stilstand en verstarring in godsdienservaring sou lei. Hy wil vanuit sy piëtistiese verlede (Sommer, 1989:310-312) van geen teoretiese Christelike geloof weet nie en vra vir preke wat uiting gee aan konkrete, praktiese, kerklike geloofsgemeenskap (vroomheid).

Na die Tweede Wereldoorlog het die afkeer van preke oor geloofsleer toegeneem. Pragmatiste soos die eucumenicals in die Wêreldraad van Kerke se konfessies en nadruk op die leer verdeel en ry die organisatoriese eenheid van die 'wêreldkerk' in die wiele. Aktiviste noem doenigheid met die leer kosmetiek om die gebrek aan daadwerklike kerklike betrokkenheid by sosiopolitieke en ekonomiese struktuurveran- 
deringe in die wêreld te vermy. Die 'leer' sou die 'lewe' lamlê (vgl. Vorster, 1977:1429; Runia, 1978:29 e.v.; Botha, 1977:4-13; Vermaak, 1972:23; Duvenage, 1969:285).

Kritiek wat toenemend onder Gereformeerdes teen kategismusprediking verneem word, vertoon egter meer ooreenkoms met Schleiermacher en die piëtisme. Die 'kerk se leer' word as iets objektief en teoreties beskou wat niks met die praktiese geloof en lewe te make het nie. Na die Aufklärung vind mense dit vreemd dat Calvyn sy sterwende vrou met die doctrina (leer) kon getroos het (Schulze, 1988:27). Gepaard met die devaluasie van die 'leer' gaan die eis dat wanneer 'die kategismus' nog gepreek word, dit noodwendig altyd aan die hand van 'n teks moet geskied, sodat Skrifprediking kan plaasvind. Die oorspronklike bakens het verskuif: die 16de eeu verlang gereelde prediking van die Christelike geloof aan die hand van die Kategismus. Vandag word vir 'n kategismuspreek aan die hand van 'n teks gevra. Preke oor die Christelike geloof het preke oor die kategismus geword en mag die einde daarvan inlui.

Swak bywoning van die tweede diens word maklik aan weerstand teen die kategismuspreke toegeskrywe. Die tweede diens was egter swak bygewoon voordat daar kategismuspreke was. Stelselmatige prediking van die geloof is juis ingestel om swak bywoning van middagdienste teen te gaan (Pont, 1981:161). Tweede dienste word swakker bygewoon by kerke wat die 'kategismusprediking' laat vaar (Jonker, 1976;127 e.v.). Gereformeerde Kerke waar gereelde kategismusprediking plaasvind, konstateer nie beter bywoning wanneer byvoorbeeld met ruildienste vrye stof deur ' $n$ besoekende predikant gepreek word nie. Ek weet van gevalle waar selfs nie-gereformeerde akademici kategismusprediking opgesoek het om stelselmatig op hoogte te kom met die gereformeerde geloofsleer. Kategismuspreke kan mense opbou wat byvoorbeeld uit ander kerkgemeenskappe by die gemeente aangesluit het of wil aansluit. 'n Goeie preek wat die die lig van die Skrif laat skyn oor geloof waaruit geleef word, is funksioneel en mense vra vandag vir funksionele prediking.

Predikante kan self bydra om die aandag meer op die kategismus as op die persoonlike geloof te vestig. "Verkeerde motodes" (Grobler, 1983:105) het kategismuspreke dikwels in "dorre leerredes", uitstal van geleerdheid, stereotipe herhaling, "lewensvreemde" dogmas of stereotipe katkisasielesse laat ontaard (vgl. Grobler, 1983:32; Haitjema, 1962:13). In 'n katkisasieklas kan 'n predikant nog sê die 'kategismus leer ons hier in hierdie Sondag so'. Wanneer hy egter preek, moet die Skrif ons leer om te glo wat in die kategismus geformuleer is.

Daar is predikante wat 'modern' wil wees en beterweterig te velde trek teen wat 'oud' is. Hulle dink dat die dwalings in die tyd van die Reformasie nie meer vandag aktueel is nie en hulle skep die persepsie dat prediking oor geloof 'swaar' of 'uit die mode' geraak het. Sommige sê weer dat die 'moderne mens' lewensbeskoulik op sy huidige 
situasie ingestel is. Eksistensialisme en waardering vir ontwikkeling (ewolusie) maak die verlede, die geskiedenis en prestasies van weleer irrelevant vir vandag. Kategismusprediking sou dan outyds, uitgedien of 'n remskoen vir ontwikkeling wees. Indien 'n predikant so ingestel sou wees, kan hy self nie die belydenis deurgrond of beleef nie. Hy sal gevolglik droë siellose verhandelings oor die kategismus lewer (Schulze, 1988).

Sommige beroep hulle vir hul standpunt teen 'kategismusprediking' op 'n uitspraak van Lloyd-Jones (vgl. Jung, 1986:122 e.v.; Grobler, 1983:54, 70 e.v.; Lloyd-Jones, 1971:187). Lloyd-Jones tree egter binne die Engelse kerkwêreld op en hanteer 'n ander kerkbegrip as die Skrif en Gereformeerde Konfessies (NGB 27-29; HK Son. 21). Vir hom is die begrip church nie die Christene self nie (1971:18 e.v., 29,32 e.v., 41), maar 'n objektiewe instituut ('n kerkbus) vir gelowiges, daargestel deur organisasie en nie deur eenheid in die geloof nie. Verder praat hy van 'n gewone Engelse catechism en nie van 'n kategismus wat tot 'n konfessie verklaar is nie. 'n Kategismus is vir hom 'n leerboek, soos die Heidelbergse Kategismus oorspronklik ook bedoel was (Steenkamp, 1989:617; Engelbrecht, 1989:639 e.v.). Lloyd-Jones bepleit egter net soos artikel 68 van die Kerkorode dat die leer (doctrine) gereeld temas vir die prediking moet verskaf en hy noem daardie preke "great preaching". Hy waarsku tereg dat die leer nie abstrak, intellektualisties, akademies of selfs baie ortodoks gepreek moet word sodat die hart nooit aangeraak word nie (vgl. by Jung, 1986:161 e.v.).

Samevattend blyk dus dat daar weerstand teen kategismuspreke en prediking van die Christelike leer aan die hand van die Kategismus (of die NGB of die DIR) kan voorkom. Dit hang saam met ' $n$ institusionele kerkbegrip wat die funksie van "eenheid in ware geloof" (HK Son. 21) vir kerkwees nie meer reken nie. Die waarde van preke oor temas van geloofsbelydenis gaan grootliks verlore omdat waarskynlik minder as $15 \%$ van die gemeente die tweede diens bywoon. 'n Mens kan met Haarsma saamstem dat "wijziging onzer belijdenis naar de eisen des tijds, krachtige konfessionele tucht of goed gewaarborgde vrijheid voor allen in alles" nie die oplossing bring nie. "Herstel van de eenheid is ... slechts mogelijk door een hoogere praktijk, door een daad in eminente zin, de erkenning van 's Heeren heerschappij in de kerk" (1967:138). Indien die Christelike geloofsleer aktueel, sinvol en in sy lewensomvattende betekenis vir die koms van God se koninkryk (heerskappy) in ons wêreld van vandag gepreek word, gaan die herstel (opbou) van die gemeente hand aan hand met waardering vir gedeë verkondiging van die Christelike geloof. 'n Predikant kan gerus selektief ook die eerste diens daarvoor gebruik.

\section{KAN GELOOFSLEER GEPREEK WORD?}

Wie geloofsleer as 'n teoretiese intellektuele aktiwiteit beskou en wie geloofsleer nie 
as weergawe van Godsopenbaring nie maar as 'n produk en eiendom van die kerk as denominasie beskou, sal nie geloofsinhoude preek nie. Dijk daarteenoor ag prediking oor geloofsleer nie net moontlik nie maar ook noodsaaklik, hoewel hy moontlik die klem te veel op die rasionele en objektiewe leer van die kerk plaas.

De gemeente van deze tijd beeft onderwijs nodig. Het gaat haar ontbreken aan het rechte inzicht in wat zij belijdt. Over velen koml ook een geest van confessioneel indifferentisme. $\mathrm{Zij}$ onderscheid niet meer wat waarheid en niet-waarheid is, en daarom is het broodnodig, dat met name in de Catechismuspreek aan de gemeente verkondigd word wat echt bijbels-gereformeerd is, en wat het geloof inhoudt ... en in de Catechismusprediking moet uitkomen, dat de prediker mct heel zijn hart op de 'leer der kerk' een duidelijk amen uitspreckt. De Catechismus is maar nict een simpel leerboek, een catechisatieboekje ... Hij beboort tot het gereformeerde Credo, cn de preek over dit Credo bedoelt Zondag aan Zondag de kerk des Heren haar eigen geloofsamen voor te houden en in de naam van Jezus Christus te dringen tot heilige ernst met dit amen (Dijk, s.j.:7 e.v.).

Vir Calvyn was geloof baie prakties. Van hom is al gesê dat hy bo Augustinus uitgaan omdat hy alles stuur in die rigting van glo en wat geglo word (Haarsma, 1967:24). Geloof val uiteen in 'n menslike atkiwiteit van glo (actus) en 'n inhoud (habitus) wat geglo word. Geloofsbelydenis speel gevolglik by elke preek reeds 'n praktiese rol. "Die gemeente se verwagting van die preek word verder gekondisioneer deur die Belydenisskrifte ...". Elke godsdiens het 'n kern, 'n sentrale motief, van waaruit so 'n godsdiens verstaan moet word (Pieterse, 1989:593). In 'n sekere sin gaan elke preek wyer as die teks waaruit gepreek word omdat die teks in die totaliteit van God se openbaring behandel word. Die Skrif word gelees vanuit geloof met die oog op geloof (Pieterse, 1989:589,593). In meerdere of mindere mate word geloofsleer of geloofsoortuiginge in elke preek gepreek. Geloofsleer kan dus gepreek word.

Wie deur die Heilige Gees verlig word, gryp die geopenbaarde waarhede in die Bybel aan en kry hulle lief (Lloyd-Jones, 1971:50 e.v.). Predikante kan gerus onthou dat Lloyd-Jones sê dat goeie prediking op goeie temas berus. Wanneer groot waarhede van die Bybel in 'n geloofsbelydenis saamgevat is, bied daardie geloofsbelydenis temas wat groot prediking tot gevolg kan hê. Sulke preke gaan ver bo sedelesse, sosiopolitieke praatjies of mottoprediking uit (vgl. Lloyd-Jones, 1971:13).

Die belydenis vorm 'n eie genre van tematiese preekstof wat van gewone prediking uit die Ou-Testamentiese en Nuwe-Testamentiese stowwe verskil (Dijk, 1955:hfst. 8-10). Prediking van die geloofstemas vereis daarom ook 'n eie metode. Die metode stem in 'n sekere opsig formeel ooreen met liriese stowwe of selfs waar wysheidsliteratuur uit die Skrif gehanteer word. 'n Belydenis het dit met 'n digter of liriek of selfs wysheidsliteratuur gemeen dat die kerk (gelowiges) onder verligting van die Heilige Gees antwoord op wat God openbaar. 'n Belydenis word soos 'n psalm biddend op sy eie kraambed gebore en nie by 'n studeertafel gemaak nie. Natuurlik is die geloofs- 
belydenis nie geïnspireerd en met dieselfde gesag as die Psalms of Prediker beklee nie (NGB 7). Die Heidelbergse Kategismus kan egter slegs waarlik geloofsbelydenis wees wanneer die kerke daarin die taal van die geïnspireerde Woord van die Heilige Gees erken het (NGB 2,7,32). Die geloofsbelydenis wil immers net die Skrif naspreek totdat die teendeel bewys is. In kategese dien die kategismus om die Skrif te leer verstaan. Wie egter die geloof uit die kategismus preek, moet altyd weer aantoon hoe die belydenis uit die Skrif bekom is en met die Bybel ooreenstem.

\section{HOE MOET DIE GELOOFSLEER AAN DIE HAND VAN DIE KATEGISMUS GEPREEK WORD?}

Hyperius (ong. 1564) beskryf prediking as "bediening van die Woord" dit wil sê uitleg en toepas van die Woord (Hoekstra, s.a.:108 e.v.). Gewone prediking neem 'n teks of perikoop as vertrekpunt om te verklaar en toe te pas (vgl. Hoekstra, s.a.:117 i.v.m. Walaeus, ong. 1634). Die sogenaamde kategismuspreek neem egter 'n tema uit die homologia van die gemeente as vertrekpunt. Die leerstuk berus waarskynlik op verskillende Skrifgedeeltes. Prediking van 'n tema wat gegrond is op verskillende tekste en Skrifgedeeltes, moet dienooreenkomstig behandel word en is net so goed Skrifprediking as wanneer een teks gepreek word. Die vraag is slegs of die prediker by die sogenaamde kategismusprediking die Skrif laat praat.

Die Heidelbergse Kategismus dra net soos baie psalms die $e k$-toon maar reik tog na die universele uit en lewer in die ek-toon 'n kollektiewe gemeentelike respons op die openbaring van God (Dijkstra, 1980:40 e.v.). My-geloof word onder verligting van die Heilige Gees ons-homologia. Die prediker moet by elke tema in die geloofsbelydenis soos by elke psalm vra na die unieke konteks, doel en gerigtheid van daardie belydenisuitspraak. Hy moet weet hoekom en hoe die aspek van belydenis ontstaan het. Te veel predikers benader die belydenis tydloos en neutraal. Eers wanneer die prediker die belydenis in die lewe gevind het, kan hy hom verdiep in die Skrifopenbaring oor die onderwerp. 'n Preek oor 'n geloofstema, neem eers vorm aan wanneer Skrifopenbaring in die preek konkretiseer en vra allermins na intellektuele vermoëns, spekulasie of abstrakte beskouinge. Talle Sondagsafdelings in die Heidelbergse Kategismus (vgl. $1,7,21,23)$ is so eksistensiëel dat dit tot liedere van geloof opklim wat die lewe en ervaring van die gemeente weergee (vgl. Jung, 1986:120).

Die sogenaamde kategismuspreek hou vir die prediker die voordeel in dat hy met sinsontleding uit die belydenis die tema van sy preek kan vasstel nog voordat hy detail. of diakroniese eksegese gedoen het. Die homiletiese beginsels en riglyne wat Dijk vir liriek en wysheidstowwe uitwys (1955:216 e.v., 225 e.v.), kan ook hier toegepas word. Die prediker moet vra na die situasie waarin die belydenis ontstaan het, hoe die band 
tussen Christus en die volk van God daarin uitgedruk word, hoe die individu en gemeenskap geloof daarin bely en beleef, watter lewenservaring of situasie die belydenis in die geskiedenis en veral vandag belig, hoe die tema aansluit by die geheel van die belydenis en veral wanneer bely die hoorder waarlik wat in die kategismus geformuleer word.

\section{DIE VERSKIL TUSSEN VRYESTOF- EN DIE KATEGISMUSPREEK}

Die wanopvatting kom soms voor dat teksprediking die Skrif en kategismusprediking die kategismus as bron het. Die vraag is egter of slegs teksprediking Skrifprediking is. Ons wil met nadruk beweer: die enigste bron vir prediking is die verskillende soorte preekstowwe in die Skrif (Dijk, 1955:197). In gereformeerd-wees gaan dit om sola scriptura (NGB 7). Op sigself bied geloofsleer en 'n kategismus geen teks of gesag vir die prediking nie. Slegs God se Woord kan gepreek word. Sommige wil voorkom dat die kategismus op sigself die bron vir die prediking word en probeer elke preek aan die hand van 'n teks maak. Om egter kategories te sê "kategismusprediking is teksprediking" (Grobler, 1983:80), laat dink aan Amesius (Schulze, 1988:27). Daar is meer vorme van Skrifprediking as 'teksprediking'. 'n Preek met 'n tema uit die belydenis wat die Skrif diakronies agter die belydenis uitlig, is Skrifprediking.

Vryestof-preke eksegetiseer 'n 'teks' uit die Skrif (vers of perikoop). Uit die eksegese word die hoofgedagte bepaal. Die tema wat die preek dra, word dus na eksegese geformuleer om daarna uit die konteks van die teks die preek te bou. By die maak van die sogenaamde kategismuspreek is die volgorde egter net mooi omgekeer. Die tema vir die preek word in die geloofsleer gegee voordat die prediker 'n enkele teks gekies of enige eksegese gedoen het. Ons herinner weer aan die oorspronklike bewoording van artikel 68 van die Kerkorde: die hoofpunte van die Christelike leer (geloof as inhoud) moet sistematies aan die hand van die kategismus gepreek word.

Die kategismus kan nie 'n 'teks' vir 'n preek gee nie (vgl. Grobler, 1983:72 e.v.) maar wel die tema van die preek verskaf. 'n Mens kan nie die kategismus soos die Skrif eksegetiseer nie. Wie dit sou probeer doen, sal in die tematiese of mottoprediking van Van Oosterzee beland (Hoekstra, s.a.:133) waar die preek uit en om die tema gespin word of so 'n 'preek' sal in eenrigting-katkisasie verval.

Van Oosterzee (ong. 1882) se temapreek is "een aaneengeschakelde toespraak van christelijk godsdienstigen inhoud, in ongebonden stijl" oor 'n tema of motto wat bedoel is om die gemeente te stig (Hoekstra, s.j.:133) en kom op sy beste neer op 'n religieuse redevoering oor 'n onderwerp wat aan 'n teks ontleen is (Ibid:138). Ek het self talle 'kategismuspreke' gehoor wat as teksprediking aangebied word om dit na Skrifpredi- 
king te laat lyk. Die meeste van die preke het nie die tema van die kategismus nie en ook nie werklik die teks in konteks verkondig nie. So 'n preek is nie 'n vryestof-preek nie en stimuleer ook nie tot oortuiging en belydenis nie omdat Skrif nie diakronies met Skrif vergelyk word nie.

'n Bepaalde piëtistiese beskouing erken net teksprediking as Skrifprediking. Dit lei by kategismuspreke daartoe dat 'n teks aangekondig maar die kategismus geheel of gedeeltelik behandel word. Dié akrobatiek lei of na 'n kapstokpreek wat 'n geloofstema aan een enkele tekspen ophang of dit word 'n vryestof-preek met 'n paar verwysings na die kategismus. Ek het ook 'preke' gehoor wat tussen teks en kategismus twee rye spore loop.

Die kategismus as geloofsbelydenis bied egter temas wat berus op amptelike eksegese wat die kerk as geloofsgemeenskap oor eeue gedoen het. Die geloofsbelydenis gee "n gesistimatiseerde samevatting van hoe die kerk die boodskap van die Skrif verstaan" (Ebeling, aangehaal deur Pieterse, 1989:593). Die prediker gaan by die maak van die kategismuspreek dus met die tema terug na die Skrif toe om weer die Skrif agter daardie geloofstema aan die woord te stel. In talle gevalle sal meer as een teks daarvoor gebruik moet word. Wie die tema van belydenis gebruik om werklik die Skrif in openbaringsverband aan die woord te stel, laat die gemeente weet wat God sê (Jonker, 1976:132). Kategismusprediking kan in miskien die meeste gevalle nie as teksprediking aangebied word nie. Preke aan die hand van belydenistemas vorm 'n eie genre van prediking.

Die opsetlike doel van kategismusprediking is juis om verskillende tekste diakronies en vergelykend aan die woord te stel (Heystek, 1989:30). Vryestof-preke is daarteenoor "text-thematic" (Pieterse, 1987:117). Kategismusprediking vra na die hele Skrifopenbaring waarop die besondere belydenis gegrond is. Meermale sal verskillende perikope by die Skriflesing voorkom en moontlik nog meer diakronies in die preek gebruik word. Alle tekste wat gebruik word, hoef nie gelees te word nie. Die geloofstema moet die tekste bind. Jonker sè tereg dat om die Christelike leer te preek die "heilswoord waardeur 'n mens gered word" aan die orde kom. Hier gaan dit om 'n "verband van tekste" en "nie oor een teks" nie (1976:131 e.v.). Wat is meer eksistensiëel omvattend en 'prakties' as my ellende, hoe ek verlos word en hoe ek volgens God se Wet en in gebed moet lewe?

Om op te som: In gewone teksprediking word Skrif met Skrif vergelyk om die Godsopenbaring in die bepaalde teks te verstaan en toe te pas. Die kategismus verplig die prediker om in omgekeerde volgorde van geformuleerde Christelike waarhede in die belydenis na die Skrifopenbaring terug te gaan en te ontbloot op watter Woord die belydenis rus. Prediking van die hoofinhoud van die Christelike leer moet opnuut 
bevestig dat en wat ons glo op die Skrif gegrond is (NGB, 7). Die hoofpunte van die leer kan ook aan die hand van ander belydenisskrifte gepreek word. So bied die NGB geleentheid om die belydenis oor die Skrif, die kerk, die dienste ensovoorts aan te sny. Die Dordtse Leerreëls is weer vir die heilsorde en volharding van die gelowiges van belang.

\section{HOE MOET KATEGISMUSPREDIKING GESKIED?}

Wie belydenistemas preek, moet onthou dat mense verskil in vermoè, instelling, intellek, ervaringswêreld, beroepsaktiwiteite, ensovoorts. Mense vra vandag dikwels liewer na "een bedrijvig praktisch Christendom" (Dijk, s.j:5). Hulle stel belang in belydenis en geloof wat hulle kan gebruik. Die leer moet dus funksioneel en nuttig gepreek word. Die prediker preek vir sommige in die gemeente wat die geloof bely en belewe, vir ander wat nog van ver af luister (evangelisasie) en nog ander wat ten spyte van hulle belydenisaflegging uit hulle situasie ' $n$ afkeer van die 'leer' in hulle omdra. Ook preek die prediker vir sommige wat nog met katkisasie of Bybelstudie besig is. Hy moet reken met ander wat slagoffers van die tydsgees geraak het en reeds die geloof bevraagteken. Werke soos die van Van der Walt (1990) kan illustreer hoe geloofstemas onder verskillende mense in praktyke van mens-wees verskillend funksioneer. Die prediker moet in sy uiteensetting begrip en simpatie toon vir die wye verskeidenheid mense wat vandag na die kategismuspreek luister.

Wie kategismus preek sonder dat hy weet watter egte menslike nood hy betrek, moet liewer nie preek nie. Te veel kategismuspreke begin en eindig met 'kategismus' asof dit om 'n objektiewe stuk leer of teorie gaan. Die prediker kom nie met die kategismus by die lewe van die gelowiges van vandag uit nie (vgl. Jonker, 1976:132 e.v). Ondersoeke onder nasionale dienspligtiges het openbaar dat hulle die indruk het dat predikers leersuiwerheid hoog op prys stel, maar glad nie daarin slaag om leersuiwerheid as "leefvaardig" oor te dra nie (Boshoff, 1990:16). Wanneer die belydenis nie aktueel en funksioneel gepreek word nie, is die geloofstaal van die vaders vir die gemeente vreemd (Dijk, 1955:412). Daarmee sê ek nie dat die Drie Formuliere van Eenheid nie meer dinamies vertaal kan word nie.

Talle predikers verval in die slegte gewoonte om die kategismus op die preekstoel soos in 'n katkisasieklas te staan en parafraseer (Dijk, 1955:410). Sodoende gaan die prediking in klasgee op. Hoewel alles waar en suiwer gesê mag word, is stelselmatige onderrig nie prediking (proklamasie) nie. Ook moet die prediker waak om deur swak woordkeuse of preektegniek selfs net die indruk te gee dat hy die kategismus as bron en finale gesag vir die prediking beskou. 
Die Woordbediening aan die hand van die kategismus stel die prediker in die versoeking om te redeneer, filosofeer of aanvalle op teenstanders te loods. Bestry 'n sonde (dwaling), nie die sondaar nie (Dijk, 1955:411). Dit hinder wanneer dwalings afgewys word met frases soos 'die kategismus leer ons hier ...' of nog erger: 'Hoor wat die kategismus sề .... Sodanige frases suggereer dat deur die kategismus en nie deur die Skrif nie, die bron van gesag teen dwalings verskaf word. Die gemeente moet hoor wat God vir hulle sê sodat hulle die belydenis kan nasê.

Lloyd-Jones sê tereg dat "they will come and ... do come when it is true preaching" wat die Heilige Gees gebruik om geloof te bou (1971:51). Die leer moet so gepreek word dat die hoorder daarmee binne die werklikheid van sy lewe 'n bewoë antwoord op die lewende Woord van God deur die verligting van die Heilige Gees kan gee. Dit is belydenis. Die Heilige Gees moet nie verhinder of teengestaan word met allerlei dogmatiese beskouinge of dor en droë verhandelinge of vryblywende kennis oor God se werk in natuur en genade nie (Dijk, s.j.:6). Die prediker moet wat hy preek met die hart glo en innig met die mond bely (NGB art. 1).

\section{SAMEVATTEND}

Die prediking van die hoofinhoud van die leer is aktueel. Ondersoek by byvoorbeeld nasionale dienspligtiges bewys dat prediking oor die leer in aanvraag is, mits dit prakties gekonkretiseer word. Dit is vasgestel dat "ten spyte van die feit dat hulle pas belydenis van geloof afgelê het, daar by hulle ontsaglike behoefte is na die abcwaarhede van die geloof" (Boshoff, s.j.:13). Hulle kry met 'n diversiteit van ander lewensbeskouings en gelowe te doen en staan weerloos in 'n 'deurmekaar' wêreld as hulle nie weet wat en waarom hulle so glo en wat dit prakties beteken nie. Daarom moet die Skrif deur die taal van die belydenis vir 'n situasie van vandag spreek.

'n Prediker kan die prediking van die hoofinhoud van die geloof verongeluk wanneer hy die kategismus objektief as 'n voorwerp van geloof in plaas van as subjektiewe uitdrukking van die geloof aanbied (Pieterse, 1979:58 e.v.). Dijk stel gevolglik drie eise aan hierdie prediking: dit moet bediening van die Woord wees, dit moet geloofstaal verklaar en dit moet vir die hede aktueel wees (1955:413). Die prediker se doel moet veral nie by 'leersuiwerheid' soos in 'n kerklike eksamen bly steek nie. Preke oor die hoofsom van geloof moet in funksionele 'leefvaardigheid' konkretiseer (Boshoff, 1990:16) 


\section{BIBL IOGRAFIE}

ANON. 1989. Die kategismuspreek se teks. Dr. A Kuyper se standpunt. Die Kenkblad,11(1):21.

BIESTERVELD, P. \& KUYPER, H.H. 1905. Kerkelijk handboekje bevattende de bepalinge der Nederlandsche Synoden ... Kampen : Bos.

BOSHOFF, H. s.j. Die kerk en die negentigerjare. Potchefstroom : PU vir CHO. ITS.

BOSHOFF, H. 1990. Samelewingveranderinge en die kerk in die negentigerjare: Moontlike implikasies. Potchefstroom. PU vir CHO : ITS.

BOTHA, L.J. 1977. Die Sendingkonferensic van die GES te Kaapstad op 2-6 Augustus 1976 - 'n terugblik. In die Skriflig, 11(41):4-13. Maart.

BOUWMAN, H. 1925. Belijdenisschrift. (In Grosheide, F.W. e.a. red. Christelijke Encyclopacdie voor het Nederlandsche volk. Kampen : Kok. p. 274-2m.)

CALVYN, J. 1951. Die Institusie van Calvyn. Verkort weergegee deur A. Duvenage e.a. Blocmfontein : Sacum.

D'ASSONVILLE, V.E. 1976. Die dwaasheid om te preek. Johannesburg : De Jongh.

DE KLERK, BJ. 1937. Vorme en karakter van die Biblisisme. Kampen : Kok.

DE WET, C.J H. \& COETZEE, J. CHR. 1943. Die beginsels, metode en geskiedenis van dic kategetiese onderwys. Kaapstad : Nasionalc Pers.

DIE HEIDELBERGSE KATEGISMUS

DIJK, K. 1955. Dienst der prediking. Kampen : Kok.

DIJK, K. s.j. De Catechismuspreek in haar verscheidenheid. Franeker : Wever.

DIJKSTRA, H. 1980. Die aard van die persoonlike toespitsing van die heil in die Heidelbergse Kategismus. In die Skriflig 14(56):40-53.

DU PLOOY, A. le R. 1989. Kollegialisme. In die Skriflig 23(91):2-11. September.

DRESSEL, L. 1988. Wat is die erediens wat vernuwe moet word? (In Smuts, A.J. red. Prakticse tcologic in SA, vernuwing en die erediens. Pretoria : NGKB.)

DUVENAGE, B. 1969. Die religieuse grondmotief van die konsepsies van Visser 't Hooft m.b.l. dic Wêreldraad van Kerke. Potchefstroom : PU vir CHO.

DUVENAGE, S.C.W. 1958. Kategismusprediking. Koers, 26(4):157-164. Oktober.

ENGELBRECHT, B.J. 1989. 'n Vergelyking tussen die teologie van die Nederlandse Goloofsbelydenis en die Heidelbergse Kategismus. Henormde Teologiese Studies, 45(3):626-644. September.

GASSMANN, B. 1968. Eeclesia Reformata. Die Kirche in den reformierten Bekenntnisschriften. Freiburg: Herder.

GKSA 1980. Kerkorde van die Gereformeerde Kerke in SA. Potchefstroom : KJBF.

GKSA 1990. Acta Suidelike Partikuliere Sinode. Petrusburg.

GROBLER, C.S. 1983. Kategismusprediking - Is dit Skrilprediking? Potchefstroom (Verhandeling (Th.M.) PU vir CHO.)

HAARSMA, F. 1967. Geest en Kerk. Utrecht : Ambo.

HAITJEMA, T.L. 1962. De Heidelbergse Catechismus. Wageningen : Veenman.

HANEKOM, T.N. 1951. Die liberale rigting in Suid-Afrika. Stellenbosch : CSV Bockhandel.

HEYSTEK, N. 1989. Die kategismuspreek. Die Kerkblad, 91(2821):30, Febr.

HOEKSTRA, T. s.a. Homiletiek. Wageningen. Zomer en Keunig.

HONIG, A.G. 1925. Catechismus. (In Grosheide, F.W. e.a. red. Christelijke Encyclopaedie voor het Nederlandse volk. Kampen : Kok. p. 430 e.v.).

JONKER, W.D. 1976. Die Woord as opdrag. Gedagtes oor die prediking. Pretoria : NGKB.

JUNG, K.D. 1986. An evaluation of the principles and methods of D.M. Loyd-Jones. Potchefstroom (Proefskrif (Th D) - PU vir CHO.)

KÜNG, H. 1973. The Church. London : Search Press.

KUYVENHOVEN, A. 1989. Preach the Catechism! The Banner, 124(8):6. February.

LINDEBOOM, C. s.j. Formulieren van Eenigheid. (In Grosheide F.W. e.a. red. Christelijke Encyclopaedie voor het Nederlandse volk, Kampen. Kok. p. 189.) 
LLOYD-JONES, D.M. 1971. Preachers and preaching. London : Hodder and Stroughton.

MILNER, B.C. 1970. Calvin's doctrine of the church. Leiden : Brill.

NEDERLANDSE GELOOFSBELYDENIS.

OBERHOLZER, J.P. 1989. Die Heidelbergse Kategismus in sy eerste jare. Hervormde Teologiese Studies, 45(3):598-610. September.

PIETERSE, H.J.C. 1989. Prediking en geloofservaring: Gesprek oor die teologiese gehalte van dic preck. Hervormde Teologiese Studies, 45(3):586-597. September.

POLMAN, A.D.R. s.j. Onze Nederlandse Geloofsbelijdenis. Deel III. Franeker : Wever.

PONT, A.D. 1981. Die historiese agtergronde van ons kerklike reg. Pretoria : Kittal.

PRETORIUS, LA. 1967. Die Heidelbergse Kategismus. Hervormde Teologiese Studies, 23(4):60-91.

RIDDERBOS, H. 1950. De komst van het koninkrijk. Kampen : Kok.

RUNIA, K. 1978. De Wereldraad in discussie. Kampen : Kok.

SCHLEIERMACHER, F.D.E. 1968. Schleiermacher-Auswahl. Mit einem Nachwort von Karl Barth. Munchen und Hamburg : Siebenstern Taschenbuch Verlag.

SCHULZE, L.F. 1988. Dic kalegismusprediking in die krisis. In die Skriflig, 22(88):24-31.

SCHULZE, L.F. 1989. Is kategismusprediking nog aktueel? Die Kerkblad, 91(2815):25, Maurt; 92(2816):15-16, April; $92(2817): 10-11$, A pril.

SNYMAN, WJ. 1977. Nuwe en ou dinge. Potchefstroom : Pro Rege.

SOMMER, W. 1989. Die Stellung Semler und Schleiermacher zu den reformatorischen Bekenntnisschriften. Kerugma und Dogma, 35(4):296-315. Okt./Dez.

SPOELSTRA, B. 1975. Persoonlikhede in die vroeë Anabaptisme - was die Wederdopers rewolusioniste of hervormers? In die Skriflig, 9(36):37-51. Desember.

SPOELSTRA, B. 1978. Calvyn en die grense van die kerk. In die Skriflig 12(45):20-37. Maart.

SPOELSTRA, B. 1984. Gereformecrde kerkbegrip en kerklidmaatskap. In die Skriflig, 18(70):20)-32. Julie.

SPOELSTRA, B. 1986. Hct ons kerk-wees in strukture gestol? Henomde Teologiese Studies, 42(1):94. 109. Maart.

SPOELSTRA, B. 1988. Kerkeenheid en meerdere vergaderings. In die Skriflig 22(85):37-52.

SPOELSTRA, B. 1989. Gereformeerde Kerkreg en kerkregering. 'n Handbock by die Kerkorde. Hammanskraal : Hammanskraalse Teologiesc Skool.

SPOELSTRA, B. 1990. Gereformeerde Kategetiek en Kategese. Afd. I. Prinsipiële Katcgetick Diktaat. Potchefstroom: PU vir CHO.

STEENKAMP, J J. 1989. Ursinus, die opsteller van die Heidelbergse Kategismus, Olevianus en die Heidelbergse Teologie. Hervormde Teologiese Studies, 45(3):611-625. September.

TIMMER, J. 1989. Heidelberg Catechism. A preacher's guide to the sixteenth century. The Banner, 124(8):8-9, Febr.

TRIMP, C. 1989. Het verschijnsel 'preek'. De Reformatie, 64(27):553-555. April.

URSINUS, Z. 1886. Verklaring op den Heidelbergse Catechismus. Uit Latyn vertaal, C. van Proosdij. Kampen : Zalsman.

VAN DER LEEUW, G. 1946. Liturgiek. Nijkerk : Callenbach.

VAN DER WALT, B.J. 1990. Om mens te wees. Gawe en opgawc. Potchefstroom : PU vir CHO/IRS. F3(50).

VAN 'T VEER, . 1942. Catechese en catechetiesche stof bij Calvijn. Kampen : Kok.

VELTHUYSEN, G.C. 1989. Die verhouding tussen die Heidelbergse Kategismus en die Kortbegrip van Faukelius - met besondere verwysing na die teologiese klemverskuiwings in laasgenoemde. Hervormde Teologiese Studies, 45(3):645-654. Seprember.

VERMAAT, J.A.E. 1972. Kerk en Tegenkerk. De oecumenische beweging getoetst aan die Heilige Schrift, Amsterdam : Buijten \& Schipperhein.

VORSTER, J.M. 1977. Die kerk in die moderne wêreld - 'n diagnose. In die Skriflig, 11(41):14-29. Maart.

WIELENGA, B. s.j. Onze Catechismus. Deel I. Kampen : Kok. 